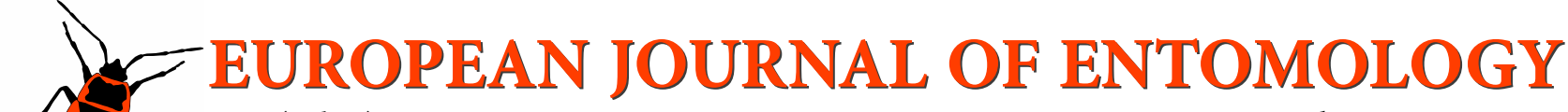 \\ ISSN (online): 1802-8829 \\ http://www.eje.cz \\ Eur. J. Entomol. 117: 110-117, 2020 \\ doi: 10.14411/eje.2020.012 \\ ORIGINAL ARTICLE
}

\section{Is Isaria fumosorosea selective to Trichogramma pretiosum (Hymenoptera: Trichogrammatidae)?}

\author{
Michele POTRICH ${ }^{1}$, Gabriela LiBARDONI $^{1,2}$, Luis F.A. ALVES ${ }^{3}$, VANDA PIETROWSKI ${ }^{4}$, Everton R.L. da SILVA ${ }^{1}$ \\ and PEDRo M.O.J. NEVES ${ }^{2}$ \\ ${ }^{1}$ Biological Control Laboratory, Universidade Tecnológica Federal do Paraná (UTFPR), Campus Dois Vizinhos \\ (Federal University of Technology - Paraná), Dois Vizinhos, Brazil; e-mails: profmichele@gmail.com, evertonloz@gmail.com \\ ${ }^{2}$ Microbial Control of Insects Laboratory, Universidade Estadual de Londrina (UEL), Londrina, PR, Brazil; \\ e-mails: gabrielalibardoni@gmail.com, pedroneves@uel.br \\ ${ }^{3}$ Agricultural Biotechnology Laboratory, Universidade Estadual do Oeste do Paraná (Unioeste), Cascavel, PR, Brazil; \\ e-mail: Luis.Alves@unioeste.br \\ ${ }^{4}$ Agrarian Science Center, Universidade Estadual do Oeste do Paraná (Unioeste), Marechal Cândido Rondon, PR, Brazil; \\ e-mail: vandapietrowski@gmail.com
}

Key words. Hymenoptera, Trichogrammatidae, Trichogramma pretiosum, Isaria fumosorosea, Anagasta kuehniella, egg parasitoid, entomopathogenic fungus, selectivity

\begin{abstract}
Entomopathogenic fungi and the egg parasitoid Trichogramma pretiosum Riley (Hymenoptera: Trichogrammatidae) might be used together in biological control. However, the effects of these fungi on $T$. pretiosum are not known. Thus, this study aimed to determine the effect of the entomopathogenic fungus Isaria fumosorosea, on the biological parameters of T. pretiosum. Two isolates of $I$. fumosorosea (IBCB 367 and IBCB 394) were used for this purpose. (1) In a free choice test: cards $(1.0 \times 5.0 \mathrm{~cm})$ with non-parasitized eggs of Anagasta kuehniella Zeller (Lepidoptera: Pyralidae) were either sprayed with $0.2 \mathrm{~mL}$ of the fungus suspension $\left(1.0 \times 10^{9}\right.$ conidia. $\left.\mathrm{mL}^{-1}\right)$ or with sterile distilled water containing Tween ${ }^{\circledR} 80(0.01 \%)$, which were then offered to females of T. pretiosum. (2) No choice test: the isolates were sprayed at a concentration of $1.0 \times 10^{9}$ conidia. $\mathrm{mL}^{-1}$ on cards $(1.0 \times 5.0 \mathrm{~cm})$ with $A$. kuehniella eggs. The control consisted of spraying sterile distilled water containing Tween ${ }^{\circledR} 80(0.01 \%)$. Individual females of $T$. pretiosum were confined for $24 \mathrm{~h}$ with the cards. The number of eggs parasitized, percentage of emergence, longevity, duration of the egg-adult period and sex ratio were evaluated, as well as the longevity of the females that parasitized the eggs and the mortality of the emerging adults evaluated. IBCB 367 isolate repelled T. pretiosum. The pre-parasitism and post-parasitism sprays did not affect the number of eggs parasitized or the sex ratio, however, the pre-parasitism IBCB 394 treatment the females and males survived for longer, whereas the survival of females in post-parasitism treatment with the same isolate was reduced. The presence of conidia on and mycelium of the fungus in T. pretiosum was confirmed using Scanning Electron Microscopy and a histological analysis. Isolates IBCB 367 and IBCB 394 from I. fumosorosea are selective to T. pretiosum in the laboratory.
\end{abstract}

\section{INTRODUCTION}

Parasitoids are natural enemies of insect pests and are used as biological control agents against Lepidoptera, Hemiptera and Coleoptera, especially the parasitoids belonging to the genus Trichogramma (Hymenoptera: Trichogrammatidae) (Ksentini et al., 2013; Voinovich et al., 2013). Among the important pests of tomato crops Tuta absoluta (Meyrick) (Lepidoptera: Gelechiidae) (Filgueira, 2003; Zibaee et al., 2017; Ferracini et al., 2019), is controlled by releasing Trichogramma pretiosum Riley (Gallo et al., 2002; Haji et al., 2002; Cagnotti et al., 2016). In addition, the use of Trichogramma in Brazil has resulted in better yields of tomatoes (Haji et al., 2002; Figueiredo et al., 2015).
However, tomato production is also significantly affected by whiteflies Bemisia tabaci (Hemiptera: Aleyrodidae). For the control of these insect pests there are many studies reporting promising results following the use of entomopathogenic fungi (Faria \& Wraight, 2001; Vicentini et al., 2001; Ramos et al., 2004; Potrich et al., 2011; MurilloAlonso et al., 2015; Oreste et al., 2016).

Among the entomopathogenic fungi, the species Beauveria bassiana (Bals.) Vuill., Metarhizium anisopliae (Metsch.) Sorok., Isaria fumosorosea (Wize) Brown \& Smith and Lecanicillium lecanii (Zimm.) Zare \& Gams attack several orders of insects in the field and several studies indicate they are effective (Alves, 1998; Lorenção et al., 2001; Vicentini et al., 2001; Batta, 2018; Santos et al., 2018). 
However, the increasing use of entomopathogenic fungi has raised concerns about its effects on non-target organisms such as the natural enemies (Magalhães et al., 1998; Sosa-Gómez et al., 1998; Dalvi et al., 2007; Amaro et al., 2015; Oreste et al., 2016; Potrich et al., 2017, 2018). Thus, it is important that studies on the selectivity of entomopathogenic fungi, used to control whiteflies, take into consideration their effect on $T$. pretiosum in order to determine the safety of using both these biocontrol agents together to control pests of tomatoes and other crops. It is important to note that I. fumosorosea is a fungus that has been outstanding in controlling whitefly and for which there are several commercial isolates.

Thus, it is important to know whether interactions between these control agents when applied simultaneous increase or decrease the efficiency of biological control. Thus, this study aimed to determine the effect of the entomopathogenic fungus, I. fumosorosea, on the biological parameters of T. pretiosum.

\section{MATERIAL AND METHODS}

\section{Preparation of a monosporic culture of $I$. fumosorosea and the suspension used}

Two isolates of I. fumosorosea were used, IBCB 367, which was isolated from soil from a coffee platation at Tabapuã - SP, and IBCB 394, isolated from soil from a sugar plantation at Espírito Santo do Pinhal - SP. These isolates were multiplied in sporulation medium (M.E.) in Petri dishes and incubated at $26 \pm 2^{\circ} \mathrm{C}, 14$ $\mathrm{h}$ photophase and $70 \pm 10 \% \mathrm{RH}$, for eight days. Conidia were then collected using a sterilized spatula and stored in glass tubes in a freezer at $-10^{\circ} \mathrm{C}$ (Alves, 1998; Alves \& Pereira, 1998).

To obtain monosporic cultures, conidia were suspended in 10 $\mathrm{mL}$ of sterile distilled water containing Tween ${ }^{\circledR} 80(0.01 \%)$. The suspension was stirred for one minute by vortexing and quantified using a Neubauer's chamber $\left(1.0 \times 10^{2}\right.$ conidia.mL $\left.{ }^{-1}\right)$. Then, 0.1 $\mathrm{ml}$ was spread using a Drigalsky loop in Petri dish containing the culture medium M.E. and incubated for eight days under the same conditions as described above. Subsequently, in order, to obtain a monosporic culture a colony was transferred to another plate. Suspensions for use in the bioassays were prepared using sterile distilled water containing Tween ${ }^{\circledR} 80(0.01 \%)$, shaken and quantified in Neubauer's chamber $\left(1.0 \times 10^{9}\right.$ conidia. $\left.\mathrm{mL}^{-1}\right)$.

\section{Obtention of Anagasta kuehniella and T. pretiosum}

Cards, $15.0 \times 15.0 \mathrm{~cm}$, containing sterile eggs of A. kuehniella Zeller (Lepidoptera: Pyralidae), non-parasitized and parasitized, were obtained from the Unioeste Biological Control Laboratory, Câmpus Marechal Cândido Rondon, which were produced following the procedure used by Parra (1997).

\section{Parasitism by $T$. pretiosum in free choice test}

The treatments were sprayed on two cards of $1.0 \times 5.0 \mathrm{~cm}$, with approximately 200 non-parasitized eggs of $A$. kuehniella, using a Pneumatic Sagyma ${ }^{\circledR}$ airbrush coupled to a Fanem ${ }^{\circledR}$ constant pressure pump, $1.2 \mathrm{kgf.cm}{ }^{-1}$ (procedure also used in other experiments) at a fixed distance of $30 \mathrm{~cm}$ with lateral protection. Of the fungus suspensions $\left(1.0 \times 10^{9}\right.$ conidia. $\left.\mathrm{mL}^{-1}\right) 0.2 \mathrm{~mL}$ was sprayed on one of the cards and sterile distilled water containing Tween $80(0.01 \%)$ was sprayed on the other card, this volume was sufficient to cover the eggs on each card. The procedures followed were those used by Potrich et al. (2015).
When the cards were dry, one card spayed with the fungal isolate and another sprayed with water, the control, were identified and fixed with honey syrup inside a sterilized flat bottom glass

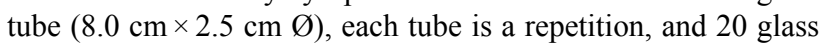
tubes were used for each treatment. Into each tube, a 24-h-old female (fed and mated) was placed and kept there for one day in the same climatic chamber $\left(26 \pm 2^{\circ} \mathrm{C}, 14 \mathrm{~h}\right.$ photoperiod and R.H. $70 \pm 10 \%$ ). According to Nogueira de Sá \& Parra (1994), Inoue \& Parra (1998) and Pratissoli et al. (2005, 2006), temperatures between 20 and 30 are the best for the parasitism of T. pretiosum, including on A. kuehniella eggs. All experiments were carried out under the above conditions.

For each isolate and respective control there were 20 repetitions. The percentage parasitism by $T$. pretiosum was evaluated by comparing each isolate with the respective control. The results were analysed using Wilcoxon non-parametric test in the statistical program BioEstat 5.0 ${ }^{\circledR}$ (Ayres et al., 2003).

\section{Parasitism by $T$. pretiosum in no choice test}

Pre-parasitism spraying: The suspensions of the isolates were sprayed on cards $(1.0 \times 5.0 \mathrm{~cm})$, containing approximately 200 sterile and non-parasitized eggs of A. kuehniella, with 20 cards per isolate and 20 cards used for the control. After spraying and drying, the cards were offered to females of T. pretiosum (fed and mated), for $24 \mathrm{~h}$.

Post-parasitism spraying: A T. pretiosum 24-h-old female (fed and mated) was confined with a card $(1.0 \times 5.0 \mathrm{~cm})$, containing approximately 200 sterile and non-parasitized eggs of A. kuehniella, in a glass tube, the female being withdrawn after $24 \mathrm{~h}$. Afterwards, 60 cards were prepared, IBCB $367\left(1.0 \times 10^{9}\right.$ conidia. $\left.\mathrm{mL}^{-1}\right)$ isolate was sprayed on 20 cards and IBCB isolate 394 $\left(1.0 \times 10^{9}\right.$ conidia.mL) was sprayed on 20 cards and sterile distilled water containing Tween ${ }^{\circledR} 80(0.01 \%)$ was sprayed on 20 cards.

The biological parameters evaluated in both bioassays were the number of blackened eggs of A. kuehniella eggs (parasitism signal) (Cônsoli et al., 1999), percentage of eggs from which adult parasitoids emerged, longevity of emerged adults, duration of the egg-adult period and sex ratio, as recorded by Hassan (1997) and using the equations proposed by Potrich et al. (2015). The longevities of the females of $T$. pretiosum that parasitized the eggs were recorded and, after death they were placed in a humid chamber to confirm they were killed by the fungus.

The data were subjected to an analysis of variance and the means were compared using the Kruskal-Wallis non-parametric test. The relationship between the treatments (pre- and post-parasitism) was compared using the non-parametric Mann-Whitney test (two independent samples ) in the statistical program BioEstat 5.0 ${ }^{\circledR}$ (Ayres et al., 2003).

\section{Histological analyses of $T$. pretiosum}

The females of $T$. pretiosum used were those that were confined with cards either with eggs of A. kuehniella sprayed with one of the two isolates of I. fumosorosea or their respective controls. The parasitized eggs that were used, were those from which adults had not emerged. Both came from the no choice parasitism test.

The samples were fixed in Bouin and dehydrated in an alcohol series and were later cleared by immersing them in xylol. After complete dehydration, paraffinization and embedding in blocks of histological paraffin wax (Histological Paraffin/Beeswax $4: 1$ ), a microtome was used to cut $2 \mu \mathrm{m}$ thick sections from the blocks with material, which were stained using the H/E method (Hematoxylin / Eosin).

The microscope slides with the sections were examined and photographed using an optical Stereo Microscope Zeiss ${ }^{\circledR}$ in the 
Laboratory of Photomicroscopy of Unioeste - Câmpus Cascavel. The tissues of the parasitoids sprayed with the isolates were compared with the tissues of the uninfected parasitoids (fom control), in addition to the spot (tissue in adults or tissue and vitelum in eggs) that showed growth of the fungus.

\section{Scanning Electron Microscopy (SEM) study}

The suspensions of entomopathogenic fungi $\left(1.0 \times 10^{9}\right.$ conidia/ $\mathrm{mL}$ ) were sprayed on cards as described above. Females (24-hold) of $T$. pretiosum (fed and mated) were confined with these cards for 1 day. The same procedure was followed for the controls. After this period, the parasitoids were prepared for studying using a SEM.

The samples (20 T. pretiosum females per treatment) were fixed for $4 \mathrm{~h}$ in a solution consisting of $2 \%$ Paraformaldehyde, $2 \% \mathrm{Glu}-$ taraldehyde and Phosphate Buffer $\left(\mathrm{PO}_{4} 0.1 \mathrm{M}\right)$. Then they were washed in phosphate buffer and fixed in $1 \%$ Osmium Tetroxide solution $\left(\mathrm{OsO}_{4}\right)$ for $2 \mathrm{~h}$ and then washed in Phosphate Buffer. After this procedure, the samples were dehydrated with a final dehydration using $\mathrm{CO}_{2}$ at the Critical Point. The samples were mounted on metallic supports (stubs) with silver glue under a Zeiss $^{\circledR}$ Stereo Microscope. The stubs with the samples were sputter coated with gold using a BAL-TEC metallizer SCD-050 and then viewed under a SEM at high vacuum and an electron beam intensity of $20 \mathrm{KV}$, with the images recorded as digital photomicrographs. Samples of the material sprayed with the two isolates of the entomopathogenic fungus were compared with the control material, in terms of the presence / absence of conidia on the body of the parasitoid and the places where these conidia were located.

\section{RESULTS}

\section{Parasitism by $T$. pretiosum in choice test}

When $T$. pretiosum females had a choice, they preferred to parasitize eggs of $A$. kuehniella that were not treated with IBCB 367 . However, the same behaviour was not recorded for isolate IBCB 394, which was not repellent to $T$. pretiosum (Table 1).

\section{Parasitism by $T$. pretiosum in no choice test}

There was no difference in the number of parasitized $A$. kuehniella eggs when they were treated with both $I$. $f u$ mosorosea isolates, prior or after parasitism, in relation to the control. There was also no difference in the number of parasitized eggs when compared to prior spraying times or after parasitism (Table 2).

When the isolates IBCB 367 and IBCB 394 were sprayed on A. kuehniella eggs prior to parasitism, they did not affect the percentage from which adults of T. pretiosum emerged, their sex ratio or the egg-adult developmental time of male and female $T$. pretiosum. Moreover, the longevities of the females and males that emerged from eggs treated with isolate IBCB 394 was longer than those of the control (Table 3).

Both isolates of I. fumosorosea sprayed on A. kuehniella eggs after parasitism by $T$. pretiosum did not affect the biological parameters of the adult parasites that emerged. However, isolate IBCB 394 caused a significative reduction in the longevity of females (Table 3 ).

Comparing the biological parameters of $T$. pretiosum that emerged from A. kuehniella eggs sprayed before and after parasitism, confirmed that the longevity of $T$. pretiosum females and males was reduced when the eggs were sprayed after they were parasitized (Table 3 ). The percentage emergence was also lower but only in the IBCB 394 treatment.

The longevity of the females that came into contact with eggs sprayed with isolates of I. fumosorosea was not affected (Table 4). Of the females that parasitized the eggs and came into contact with the isolates of I. fumosorosea, $20 \%$ of those that came into contact with isolate IBCB 394 and 55\% with IBCB 367 were killed by the fungus.

\section{Histological analyses and SEM study of $T$. pretiosum}

The histology study of $T$. pretiosum revealed the presence of hyphae, conidia and phialides (Fig. 1A and B). The tissues with the highest number of hyphae were integument, adipose tissue and nerve tissue (head region), while no hyphae were observed in the muscles. The SEM study revealed conidia in folds in the wings and on the surface of T. pretiosum (Fig. 2A and B).

Table 1. Percentage ( $\pm \mathrm{SE}$ ) of Anagasta kuehniella eggs parasitized by Trichogramma pretiosum when given the choice of eggs sprayed with Isaria fumosorosea or control eggs (temp. $26 \pm 2{ }^{\circ} \mathrm{C}$ and $14 \mathrm{~h}$ photophase).

\begin{tabular}{cc} 
Control & $46.9 \pm 10.37 \mathrm{a}$ \\
I. fumosorosea IBCB 394 & $53.1 \pm 10.37 \mathrm{a}$ \\
$p$ & 0.7699 \\
Control & $80.8 \pm 5.14 \mathrm{a}$ \\
$p$ & $19.2 \pm 5.14 \mathrm{~b}$ \\
I. fumosorosea IBCB 367 & 0.0001 \\
\hline
\end{tabular}

The total number of eggs parasitized by the confined female was considered $100 \%$ and the percentage on each card (Treatment $\times$ Control) was calculated. Averages followed by the same lowercase letter in the column do not differ from each other based on the Wilcoxon test $(p<0.05)$.

Table 2. Average numbers of eggs ( \pm SE) of Anagasta kuehniella parasitized that were sprayed with isolates of $I$. fumosorosea before or after parasitism by Trichogramma pretiosum (temp. $26 \pm 2^{\circ} \mathrm{C}$ and $14 \mathrm{~h}$ photophase) and the reduction in the parasitism capacity ${ }^{1}$.

\begin{tabular}{|c|c|c|c|c|c|}
\hline Treatment & Post-parasitism & Pre-parasitism & $p$ & ${ }^{1} \mathrm{RP}(\%)$ & Classes \\
\hline Control & $33.00 \pm 2.47 \mathrm{~A}$ & $32.65 \pm 3.15 \mathrm{Aa}$ & 0.4613 & - & - \\
\hline I. fumosorosea IBCB 367 & $33.22 \pm 1.48 \mathrm{~A}$ & $35.00 \pm 4.82 \mathrm{Aa}$ & 0.7589 & 0.00 & 1 \\
\hline I. fumosorosea IBCB 394 & $30.00 \pm 1.82 \mathrm{~A}$ & $34.50 \pm 4.12 \mathrm{Aa}$ & 0.0329 & 0.00 & 1 \\
\hline
\end{tabular}

${ }^{1} \mathrm{RP}$ - reduction in parasitism capacity compared to control; IOBC/WPRS classes for initial toxicity testing on adults: 1 - harmless (<30\%), 2 - slightly harmful (30-79\%), 3 - moderately harmful (80-99\%), 4 - harmful 100\%). Averages followed by the same lowercase letter in the column do not differ from each other based on the Kruskal Wallis test $(p<0.05)$. Averages followed by the same capital letter on a line do not differ from each other based on the Mann Whitney test $(p<0.05)$. 
Table 3. Percentage ( \pm SE) of adult Trichogramma pretiosum that emerged from Anagasta kuehniella eggs treated with Isaria fumosorosea prior to or after parasitism (temp. $26 \pm 2^{\circ} \mathrm{C}$ and $14 \mathrm{~h}$ photophase).

\begin{tabular}{|c|c|c|c|}
\hline \multicolumn{4}{|c|}{${ }^{1}$ Percentage of adults of T. pretiosum emerged } \\
\hline Treatment & Pre-parasitism & Post-parasitism & $P$ \\
\hline Control & $74.5 \pm 6.64 \mathrm{Aa}$ & $82.5 \pm$ & 0.4588 \\
\hline Eumosorosea IBC & $69.6 \pm 12.11 \mathrm{Aa}$ & 63.8 & 0.4713 \\
\hline sorosea IBCB & $88.2 \pm 6.59 \mathrm{Aa}$ & $9.95 \mathrm{Ba}$ & 0.0123 \\
\hline$p$ & 0.3793 & 0.1435 & \\
\hline \multicolumn{4}{|c|}{${ }^{1}$ Sex ratio of $T$. pretiosum } \\
\hline Control & $0.61 \pm 0.07 \mathrm{Aa}$ & 0.74 & 0.2319 \\
\hline fumosorosea IBCB 367 & $0.68 \pm 0.06 \mathrm{Aa}$ & $0.67 \pm 0.04 \mathrm{Aa}$ & 0.2919 \\
\hline fumosorosea IBCB 394 & $0.61 \pm 0.05 \mathrm{Aa}$ & $0.65 \pm 0.05 \mathrm{Aa}$ & 0.2862 \\
\hline$p$ & 0.2322 & 0.4388 & \\
\hline \multicolumn{4}{|c|}{ Egg-adult period of T. pretiosum females (days) } \\
\hline Control & $6.99 \pm 0.16 \mathrm{Aa}$ & $16 \mathrm{Aa}$ & 0.6644 \\
\hline sorose & $7.09 \pm 0.25 \mathrm{Aa}$ & 6.66 & 0.2899 \\
\hline sorosea IBCB 394 & $7.24 \pm 0.10 \mathrm{Aa}$ & $6.88 \pm 0.17 \mathrm{Aa}$ & 0.0556 \\
\hline$p$ & 0.3700 & 0.6331 & \\
\hline \multicolumn{4}{|c|}{ Egg-adult period of T. pretiosum males (days) } \\
\hline Con & $7.20 \pm 0.18 \mathrm{Aa}$ & $7.19 \pm 0.23 \mathrm{Aa}$ & 0.8209 \\
\hline sorosea & $7.24 \pm 0.23 \mathrm{Aa}$ & $21 \mathrm{Aa}$ & 1.0000 \\
\hline BCB 394 & $7.33 \pm 0.06 \mathrm{Aa}$ & $7.29 \pm 0.17 \mathrm{Aa}$ & 0.5458 \\
\hline$p$ & 0.6361 & 0.9483 & \\
\hline \multicolumn{4}{|c|}{ Longevity of females of T. pretiosum (days) } \\
\hline Con & $1.53 \pm 0.11 \mathrm{Ab}$ & $.12 \mathrm{Aa}$ & 0.2548 \\
\hline orose & $1.87 \pm 0.25 \mathrm{Ab}$ & $5 \mathrm{Bab}$ & 0.0052 \\
\hline sorosea IBCB 394 & $2.23 \pm 0.09 \mathrm{Aa}$ & $1.17 \pm 0.08 \mathrm{Bb}$ & 0.0002 \\
\hline$p$ & 0.0011 & 0.0499 & \\
\hline \multicolumn{4}{|c|}{ Longevity of males of $T$. pretiosum (days) } \\
\hline Control & $1.53 \pm 0.10 \mathrm{Ab}$ & $1.47 \pm 0.12 \mathrm{Aa}$ & 0.4970 \\
\hline sorosea IBC & $1.79 \pm 0.14 \mathrm{Ab}$ & $1.56 \pm 0.07 \mathrm{Ba}$ & 0.0250 \\
\hline fumosorosea IBCB 394 & $2.39 \pm 0.08 \mathrm{Aa}$ & $1.38 \pm 0.12 \mathrm{Ba}$ & 0.0030 \\
\hline$p$ & 0.0005 & 0.5708 & \\
\hline
\end{tabular}

$\%$ emergence $=$ (number of adults that emerged $/$ no. eggs parasitized $) \times 100 \%$. Sex ratio $=$ no. females that emerged $/$ no. adults that emerged. Longevity and egg-adult period were calculated using weighted averages. Averages followed by the same lowercase letter in a column do not differ from each other based on the Kruskal Wallis test $(p<0.05)$. Averages followed by the same capital letter in a line do not differ from each other based on the Mann Whitney test $(p<0.05)$.
Table 4. Longevity ( $\pm \mathrm{SE}$ ) of Trichogramma pretiosum females that parasitized Anagasta kuehniella eggs sprayed with isolates of Isaria fumosorosea in no choice tests (temp. $26 \pm 2{ }^{\circ} \mathrm{C}$ and $14 \mathrm{~h}$ photophase)

\begin{tabular}{cc}
\hline Treatment & Days \\
\hline Control & $3.20 \pm 0.45 \mathrm{a}$ \\
I. fumosorosea. IBCB 394 & $2.90 \pm 0.27 \mathrm{a}$ \\
I. fumosorosea IBCB 367 & $2.90 \pm 0.43 \mathrm{a}$ \\
\hline$p$ & 0.5994 \\
\hline
\end{tabular}

Averages followed by the same letter in a column do not differ significantly from each other based on the Kruskal Wallis test.

\section{DISCUSSION}

The $T$. pretiosum repellency is not related to the species I. fumosorosea, but to the isolate used, as observed by Isaria sp. IBCB 367 and Isaria sp. IBCB 394 causing differences in the parasitism of $T$. pretiosum, with IBCB 367 being repellent. Females of $T$. pretiosum are able to identify substances on host eggs that are attractive, toxic or repellent by walking backwards and forwards over the eggs and touching them with their antennae on which there are sense organs that can detect these substances (Vinson, 1997; Srivastava et al., 2017). Toxic substances produced by the entomopathogenic fungus were probably present in the suspensions, which were obtained by scraping the culture medium to obtain conidia that would have been collected along with pieces of the fungus and the toxins (exotoxins) they contain. Although females of T. pretiosum are able to recognize toxic substances on the surface of eggs (Klomp \& Teerink, 1962; Vinson, 1998) they may reject a host egg or may determine its nutritional quality by inserting their ovipositors and if suitable parasitize them.

According to IOBC/WPRS, if a product causes less than a $30 \%$ reduction in the parasitism capacity of Trichogram$m a$, it is classified as innocuous to this parasitoid (Hassan, 1997; Hassan et al., 2000; Rampelotti-Ferreira et al., 2017), as the isolates evaluated here are (Table 2).

When the isolate IBCB 394 was applied after parasitism, the small difference in the percentage of adults that
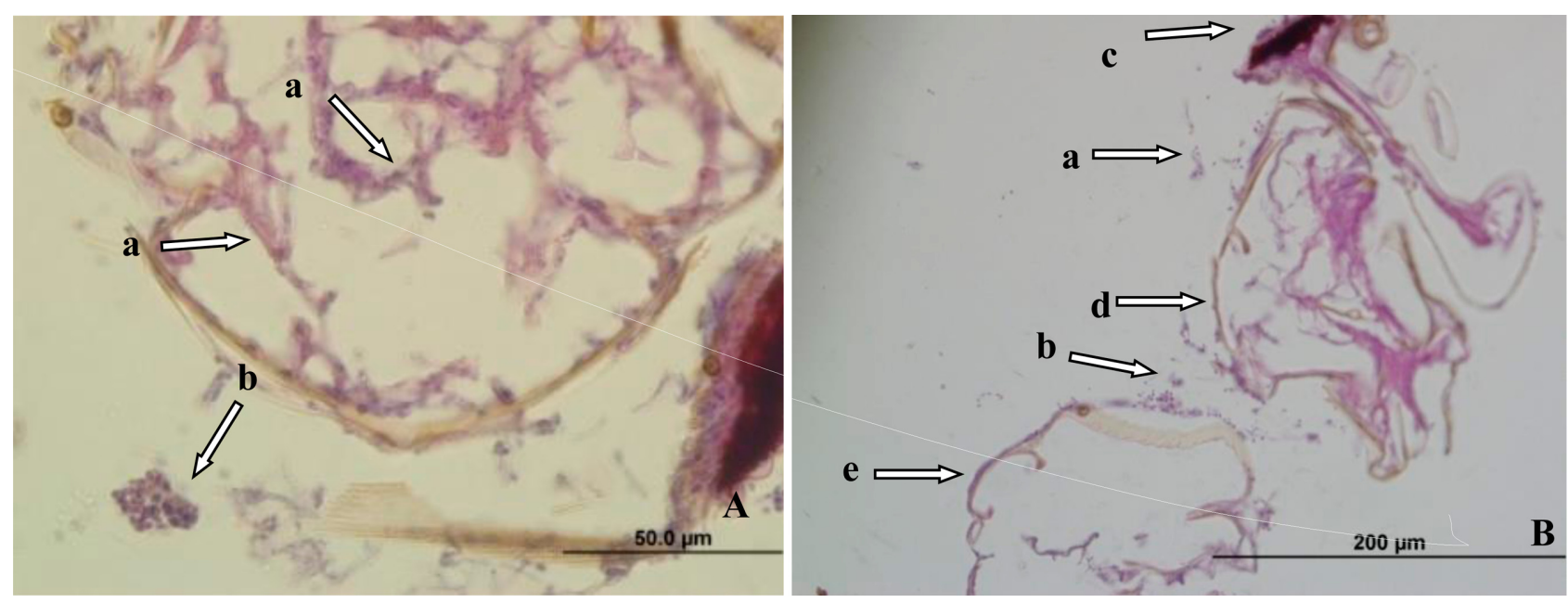

Fig. 1. Light Microscopy. A - T. pretiosum adults that came in contact with eggs sprayed with /saria fumosorosea (IBCB 367). B - adults of $T$. pretiosum that came into contact with eggs sprayed with I. fumosorosea IBCB (394). a - conidia; b - phalidus; c - eyes; $d$ - thorax; $\mathrm{e}-$ abdomen. 

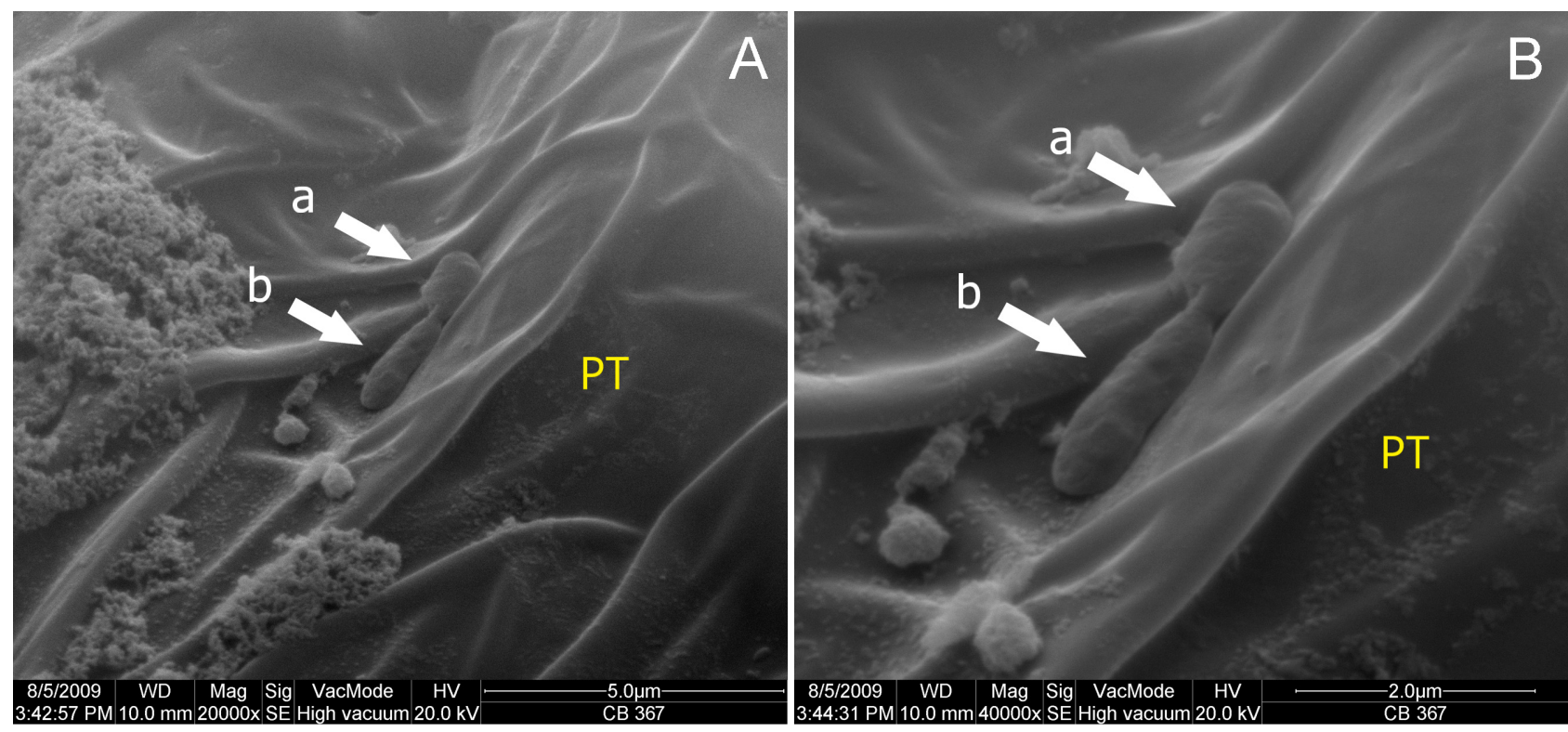

Fig. 2. A, B - Scanning Electron Microscopy (SEM) of Trichogramma pretiosum wing with germination tube. a - conidium germinating; $\mathrm{b}$ - formation of appressory; PT - ventral prothorax.

emerged (the percentage emergence was higher when previously sprayed), although significant, may be due to the eggs of the host being infected and not suitable for the development of the parasitoid. The infection of eggs by the fungus may have been due to the introduction of conidia adhering to the ovipositor of the parasitoid or by the conidia germinating on the surface of the egg and then entering via the hole made by the ovipositor or the direct action of the fungus. Thus, fungus may have penetrated and colonized host eggs internally, consuming the nutrients at the exact stage where they were necessary for the development of the immature phases of the parasitoid especially that the nutritional value of the host egg is directly related to the development of $T$. pretiosum, mainly of the females of this parasitoid.

The sex ratio of T. pretiosum was not affected by the isolates used, which were between 0.61 and 0.74 . The same is reported for the parasitoid Trichogramma atopovirilia Oatman \& Platner, 1983 (Hymenoptera: Trichogrammatidae), emerging from eggs sprayed with a solution of L. lecanii, for which the sex ratio is 0.81 and does not differ from that recorded in the control (Dalvi et al., 2007). Potrich et al. (2009) also report that the sex ratio of T. pretiosum emerging from A. kuehniella eggs sprayed with $M$. anisopliae and $B$. bassiana both before and after being parasitized does no differ from that recorded for the control, which is similar to that recorded in the present study. Using $B$. bassiana, spraying before or after parasitism, also did not affect the sex ratio of the offspring (Potrich et al., 2015).

No change was recorded in the egg-adult period of males and females of $T$. pretiosum that emerged from eggs sprayed with the isolates of I. fumosorosea. A previous study by Potrich et al. (2009) also report no difference in the eggadult period of $T$. pretiosum emerging from eggs sprayed with $B$. bassiana and $M$. anisopliae, in comparison with previous or post-parasitism application. This is important since an increase in the egg-adult period would adversely affect the bio-control effectiveness of this parasitoid.

Comparison of the pre- and post-parasitism application of IBCB 367 and IBCB 394 revealed that spraying prior to parasitism resulted in an increase in the longevity of the females and males that emerged, and this higher longevity may be related to parasitoid development in the host egg and indicate that the fungal suspension is detrimental. When host eggs are a rich source of nutrients, large and more vigorous adults may emerge, which live for longer. However, parasitoids that develope in less nutritious eggs, or those infected with fungus, may emerge smaller and less vigorous or die, or as a result of coming into contact with the isolate become infected and have a short adult life. A reduction in adult longevity is also reported for the parasitoid Trichogramma galloi Zucchi, 1988 (Hymenoptera: Trichogrammatidae) that emerge from the eggs of the sugarcane boror Diatraea saccharalis (Fabr., 1794) (Lepidoptera: Pyralidae) treated with isolate IPA159E of M. anisopliae (Broglio-Micheletti et al., 2006). Potrich et al. (2017) report that application of isolates of the fungus $M$. anisopliae affect the longevity of males and females of T. pretiosum similar to the negative effects of the isolates' IBCB 367 and IBCB 394 on the longevity of females after post-parasitism treatments in this study.

However, the isolates of I. fumosorosea may not have resulted in the death of the females that came in contact with sprayed eggs as the fungus may have infected the body of $T$. pretiosum after death. Death due to infection with entomopathogenic fungi is reported for adults of the parasitoid, Aphelinus asychis Walker (Hymenoptera: Aphelinidae), treated with I. fumosorosea isolate ARSEF 4501 (Mesquita et al., 1999).

Dalvi et al. (2007) also do not report a statistical difference in the longevity of $T$. atopovirilia females that come in contact with L. lecanii and those in the control. Simi- 
larly, Potrich et al. (2009) and Potrich et al. (2015), report that the longevity of $T$. pretiosum females that come into contact with isolates of the fungi $B$. bassiana and $M$. anisopliae when parasitizing eggs of $A$. kuehniella is not affected.

Despite the high mortality (55\%) of females of $T$. pretiosum that came into contact with the isolate I. fumosorosea, IBCB 394, and the effects of the post-parasitism treatments' on female longevity, both isolates did not affect the other biological parameters of the adults. In addition, these isolates did not affect the number of eggs parasitized compared to the control.

These results are important since they indicate that the effectiveness of $T$. pretiosum in parasitizing the eggs of pest insects is not affected. This is also highlighted by Bueno et al. (2009), who emphasize that it is parasitism that determines the efficiency of biological control in the field. When isolates of $M$. anisopliae were applied before and after parasitism, they also did not affect the number of eggs parasitized by $T$. pretiosum or the sex ratio of the emerging adults (Potrich et al., 2017).

The histological study of the immature stages of $T$. pretiosum revealed indications of infection of different tissues with $I$. fumosorosea. This may indicate that this entomopathogen can infect eggs and adversely affect the development of $T$. pretiosum, especially by decreasing the availability nutrients for the development of female parasitoids.

According to Sosa-Gómez et al. (1998) it is logical to infer that the development of a parasitoid within an entomopathogen-infected host is likely to be adversely affected. However, these authors comment that in many cases the parasitoids continuing to develope normally in hosts infected with entomopathogens. If this is the case and it does not affect longevity this is important because short lived females will parasitize fewer eggs of the host and their control efficiency will be lower.

The SEM study revealed conidia of I. fumosorosea adhering to the body of $T$. pretiosum that are difficult to clean, which renders it vulnerable to infection by entomopathogens. Although this parasitoid can clean itself by rubbing its wings and body with its legs, however, there are regions that are difficult to clean, where conidia can adhere and germinate. Joints, intersegmental membranes, folds in the wings, buccal parts and ventral regions, are the most difficult for T. pretiosum to clean. Fig. 2 indicates that conidia are present in these areas, which confirms it is difficult for this insect to clean them.

Differences between the isolates IBCB 367 and IBCB 394 may be related to the genetic variability of the isolates, the specific toxins and enzymes produced by each of them and the pathogenicity, plus the germination of the fungus on the surface of the egg and the production of metabolites, are factors that also need to be taken into consideration (Leger et al., 1986; Hajek \& Leger, 1994). Thus, in the strategies in which parasitoids and isolates are used, spaced sprays must be taken into account due to the sublethal effects that may occur. However, in this study the effects observed in the interaction between entomopathogenic fungi and T. pretiosum, were minimal and could classify the entomopathogenic fungus $I$. fumosorosea, isolates IBCB 367 and IBCB 394 as selective. Thus, based on the evaluation of several biological parameters of $T$. pretiosum it is possible to use these two control agents together.

\section{CONCLUSION}

Based on the biological parameters analyzed, I. fumosorosea (IBCB 367 and IBCB 394) can be considered selective to $T$. pretiosum in the laboratory conditions. However, based on isolates negative effects on females that carried out the parasitism and came in contact with the fungus, as well as emerging females lower longevity following post-parasitism treatments, further studies should be conducted.

\section{REFERENCES}

Alves S.B. 1998: Fungos entomopatogênicos. In Alves S.B. (ed.): Controle Microbiano de Insetos. 2nd ed. Fundação de Estudos Agrários Luiz de Queiroz, Piracicaba, pp. 289-381.

Alves S.B. \& Pereira R.M. 1998: Distúrbios fisiológicos provocados por entomopatógenos. In Alves S.B. (ed.): Controle Microbiano de Insetos. 2nd ed. Fundação de Estudos Agrários Luiz de Queiroz, Piracicaba, pp. 39-55.

Amaro J.T., Bueno A.F., Pomari-Fernandes A.F. \& Neves P.M.O.J. 2015: Selectivity of organic products to Trichogramma pretiosum Riley (Hymenoptera: Trichogrammatidae). Neotrop. Entomol. 44: 489-497.

Ayres M., Ayres Jr. M., Ayres D.L. \& Santos A.S. 2003: BioEstat 3.0. Aplicações Estatísticas nas áreas de Ciências Biológicas e Médicas. Sociedade Civil Mamirauá, Belém, 290 pp.

BATTA Y.A. 2018: Efficacy of two species of entomopathogenic fungi against the stored-grain pest, Sitophilus granarius L. (Curculionidae: Coleoptera), via oral ingestion. - Egypt. J. Biol. Pest Contr. 28: 44, 8 pp.

Broglio-Micheletti S.M.F., Santos A.J.N. \& Pereira-Barros J.L. 2006: Ação de alguns produtos fitossanitários para adultos de Trichogramma galloi Zucchi, 1988 (Hymenoptera: Trichogrammatidae). - Ciênc. Agrotecnol. 30: 1051-1055.

Bueno C.O.F.R., Parra J.R., Bueno A.F. \& Haddad M.L. 2009: Desempenho de Trichogrammatídeos como potenciais agentes de controle de Pseudoplusia includens Walker (Lepidoptera: Noctuidae). - Neotrop. Entomol. 38: 389-394.

Cagnotti C.L., Hernandéz C.M., Andormo A.V., Viscarret M., Riquelme M., Botto E.N. \& López S.N. 2016: Acceptability and suitability of Tuta absoluta eggs from irradiated parents to parasitism by Trichogramma nerudai and Trichogramma pretiosum (Hymenoptera: Trichogrammatidae). - Agric. For. Entomol. 18: 198-205.

Cônsoli F.L., Rossi M.M. \& PARRa J.R.P. 1999: Developmental time and characteristics of the immature stages of Trichogramma galloi and T. pretiosum (Hymenoptera, Trichogrammatidae). - Revta Bras. Entomol. 3: 271-275.

Dalvi L.P., Polanczik R.A., Pratissoli D., Melo R.L. \& Holtz A.M. 2007: Seletividade de Lecanicillium lecanii (Zimm.) Zare \& W. Gams (classe-forma: Hyphomycetes) ao parasitóide Trichogramma atopovirilia Oatman \& Platner, 1983 (Hymenoptera: Trichogrammatidae). —Ciênc. Agrotecnol. 31: 13921395.

Faria M. \& Wraight S.P. 2001: Biological control of Bemisia tabaci with fungi. - Crop Prot. 20: 767-778. 
Ferracini C., Bueno V.H.P., Dindo M.L., Ingegno B.L., Luna M.G., Gervassio N.G.S., Sánchez N.E., Siscaro G., van LenTEREN J.C., ZAPPALÀ L. \& TAVELla L. 2019: Natural enemies of Tuta absoluta in the Mediterranean basin, Europe and South America. - Biocontr. Sci. Technol. 29: 578-609.

Figueiredo M. De L.C., Cruz I., Silva R.B. DA \& Foster J.E. 2015 Biological control with Trichogramma pretiosum increases organic maize productivity by $19.4 \%$. - Agron. Sustain. Dev. 35: $1175-1183$.

FilgueIRa F.A.R. 2003: Novo Manual de Olericultura: Agrotecnologia Moderna na Produção e Comercialização de Hortaliças. 2nd ed. UFV, Viçosa, 412 pp.

Gallo D., Nakano O., Silveria Neto S., Carvalho R.P.L., Baptista C.G., Berti Filho E., Parra J.R.P., Zucchi R.A., Alves S.B., VendRamim J.D., Marchini L.C., Lopes J.R.S. \& OMOto C. 2002: Entomologia Agrícola. Fundação de Estudos Agrários Luiz de Queiroz, Piracicaba, 920 pp.

HaJeK A.E. \& Leger R.J.S. 1994: Interactions between fungal pathogens and insect hosts. - Annu. Rev. Entomol. 39: 293 322.

Haji F.N.P., Prezzoti L., Carneiro J.S. \& Alencar J.A. 2002: Trichogramma pretiosum para o controle de pragas no tomateiro. In Parra J.R.P., Botelho P.S.M., Corrêa-Ferreira B.S. \& Bento J.M. (eds): Controle Biológico no Brasil: Parasitóides e Predadores. Manole, São Paulo, 609 pp.

HASSAN S.A. 1997: Métodos padronizados para testes de seletividade, com ênfase em Trichogramma. In Parra J.R.P. \& Zucchi R.A. (eds): Trichogramma e o Controle Biológico Aplicado. Fundação de Estudos Agrários Luiz de Queiroz, Piracicaba, $324 \mathrm{pp}$.

Hassan S.A., Halsali N., Gray A.P., Kuehner C., Moll M., Bakker F.M., Roembie J., Yousef A., Nasr F. \& Abdelgader H. 2000: A laboratory method to evaluate the side effects of plant protection products on Trichogramma cacoeciae Marchal (Hymenoptera: Trichogrammatidae). In Candolfi M.P. (ed.): Guidelines to Evaluate Side-effects of Plant Protection Products to Non-target Arthropods. IOBC/WPRS, Reinheim, pp. 107-119.

InOUE M.S.R. \& PARRA J.R.P. 1998: Efeito da temperatura no parasitismo de Trichogramma pretiosum Riley, 1879 sobre ovos de Sitotroga cerealella (Olivier, 1819). — Scientia Agric. 55: $227-232$.

Klomp H. \& TeERINK B.J. 1962: Host selection and number of eggs per oviposition in the egg-parasite Trichogramma embryophagum Htg. — Nature 195: 1020-1021.

KsENTINI I., JARDAK T. \& ZeghaL N. 2013: A laboratory comparison of four Trichogramma species (Hymenoptera: Trichogrammatidae) as potential biocontrol agents for the carob moth, $E c$ tomyelois ceratoniae (Lepidoptera). — Biocontr. Sci. Technol. 23: 465-469.

Leger R.J.S., CoOper R.M. \& Chaenley A.K. 1986: Cuticle-degrading enzymes of entomopathogenic fungi: Cuticle degradation in vitro by enzymes from entomopathogens. - J. Invert. Pathol. 47: 167-177.

Lorenção A.L. \& Miranda M.A.C. \& Alves S.B. 2001: Ocorrência epizoótica de Verticillium lecanii em Bemisia tabaci biótipo B (Hemiptera: Aleyrodidae) no Estado do Maranhão. — Neotrop. Entomol. 30: 183-185.

Magalhães B.P., Monnerat R. \& Alves S.B. 1998: Interações entre entomopatógenos, parasitóides e predadores. In Alves S.B. (ed.): Controle Microbiano de Insetos. 2nd ed. Fundação de Estudos Agrários Luiz de Queiroz, Piracicaba, pp. 195-216.

Mesquita A.L.M., Lacey L.A., Ceianu C.S. \& Dabire R. 1999: Predatory and parasitic activity of Aphelinus asychis (Hymenoptera: Aphelinidae) following exposure to the entomopatho- genic fungus Paecilomyces fumosoroseus (Deuteromycotina: Hyphomycetes) under different humidity regimes. - Anais Soc. Entomol. Brasil 28: 661-673.

Murillo-Alonso K.T., Peña-Chora G., Hernández-Baltazar E. \& Hernández-Velázquez V.M. 2015: Conidia production by Isaria fumosorosea on solid substrates and its pathogenicity towards Bemisia tabaci. - Biocontr. Sci. Technol. 25: 175-184.

Nogueira de SÁ L.A. \& ParRa J.R.P. 1994: Biology and parasitism of Trichogramma pretiosum Riley (Hym., Trichogrammatidae) on Ephestia kuehniella (Zeller) (Lep., Pyralidae) and Heliothis zea (Boddie) (Lep., Noctuidae) eggs. - J. Appl. Entomol. 118: 38-43.

Oreste M., Bubici G., Poliseno M. \& Tarasco E. 2016: Effects of entomopathogenic fungi on Encarsia formosa Gahan. (Hymenoptera: Aphelinidae) activity and behavior. - Biol. Contr. 100: 46-53.

PARRa J.R.P. 1997: Técnicas de criação de Anagasta kuehniella, hospedeiro alternativo para produção de Trichogramma. In Parra J.R.P. \& Zucchi R.A. (ed.): Trichogramma e o Controle Biológico Aplicado. Fundação de Estudos Agrários Luiz de Queiroz, Piracicaba, pp. 121-150.

Potrich M., Alves L.F.A., Haas J., Silva E.R.L., Daros A., PIetrowski V. \& Neves P.M.O.J. 2009: Seletividade de Beauveria bassiana e Metarhizium anisopliae a Trichogramma pretiosum Riley (Hymenoptera: Trichogrammatidae). - Neotrop. Entomol. 38: 822-826.

Potrich M., Neves P.M.O.J., Alves L.F.A, Pizzato M., Silva E.R.L., Luckmann D., Gouvea A. \& Roman J.C. 2011: Virulência de fungos entomopatogênicos a ninfas de Bemisia tabaci (Genn.) (Hemiptera: Aleyrodidae). — Semina 32: 1783-1792.

Potrich M., Alves L.F.A., Lozano E., Roman J.C., Pietrowski V. \& Neves P.M.O.J. 2015: Interactions between Beauveria bassiana and Trichogramma pretiosum under laboratory conditions. - Entomol. Exp. Appl. 154: 213-221.

Potrich M., Alves L.F.A., Lozano E.R., Bonini A.K. \& Neves P.M.O.J. 2017: Potential side effects of the entomopathogenic fungus Metarhizium anisopliae on the egg parasitoid Trichogramma pretiosum (Hymenoptera: Trichogrammatidae) under controlled conditions. - J. Econ. Entomol. 110: 2318-2324.

Potrich M., Silva R.T.L., Maia F.M.C., Lozano E.R., Rossi R.M., Colombo F.C., Tedesco F.G. \& Gouvea A. 2018: Effect of entomopathogens on africanized Apis mellifera L. (Hymenoptera: Apidae). - Revta Bras. Entomol. 62: 23-28.

Pratissoli D., Zanuncio J.C., Vianna U.R., Andrade J.S., Zanotti L.C.M. \& Silva A.F. 2005: Biological characteristics of Trichogramma pretiosum and Trichogramma acacioi (Hym.: Trichogrammatidae), parasitoids of the avocado defoliator Nipteria panacea (Lep.: Geometridae), on eggs of Anagasta kuehniella (Lep.: Pyralidae). — Braz. Arch. Biol. Technol. 48: 7-13.

Pratissoli D., Polanczyk R.A., Vianna U.R., Andrade G.S. \& Oliveira R.G.S. 2006: Desempenho de Trichogramma pratissolii Querino \& Zucchi (Hymenoptera, Trichogrammatidae) em ovos de Anagasta kuehniella (Zeller) (Lepidoptera, Pyralidae) sob efeito de Bacillus thuringiensis Berliner. - Ciênc. Rural 36: 369-377.

Ramos E.Q., Alves S.B., Demétrio C.G.B. \& Costa S.C. 2004: Seleção de fungos entomopatogênicos para o controle de $B e$ misia tabaci biótipo B. - Manejo Integr. Plagas Agroecol. 73: $21-28$.

Rampelotti-Ferreira F.T., Coelho Jr A., Parra J.R.P. \& VenDRAMIM J.D. 2017: Selectivity of plant extracts for Trichogramma pretiosum Riley (Hym.: Trichogrammatidae). - Ecotoxicol. Environ. Safety 138: 78-82.

Santos T.S., Freitas A.C. de, Poderoso J.C.M., Hernandez-Macedo M.L., Ribeiro G.T., Costa L.P. da \& Mendonça M. DA C. 
2018: Evaluation of isolates of entomopathogenic fungi in the genera Metarhizium, Beauveria, and Isaria, and their virulence to Thaumastocoris peregrinus (Hemiptera: Thaumastocoridae). - Fla Entomol. 101: 597-603.

Sosa-Gómez D.R., Pereira R.M. \& Alves S.B. 1998: Impacto ambiental de entomopatógenos. Distúrbios fisiológicos provocados por entomopatógenos. In Alves S.B. (ed.): Controle Microbiano de Insetos. 2nd ed. Fundação de Estudos Agrários Luiz de Queiroz, Piracicaba, pp. 1075-1096.

Srivastava M., Singh A.K., Parihar S.G., Gautam R.D. \& Kumar V. 2017: Comparative effect of formulated kairomonal dusts on parasitization efficiency of Trichogramma spp. - J. Environ. Biol. 38: 641-648.

Vicentini S., Faria M. \& Oliveira M.R.V. 2001: Screening of Beauveria bassiana (Deuteromycotina: Hyphomycetes) isolates against nymphs of Bemisia tabaci (Genn.) biotype B (Hemiptera: Aleyrodidae) with description of a new bioassay method. - Neotrop. Entomol. 30: 97-103.
VINSON S.B. 1997: Comportamento de seleção hospedeira de parasitóides de ovos, com ênfase na família Trichogrammatidae. In Parra J.R.P. \& Zucchi R.A. (ed.): Trichogramma e o Controle Biológico Aplicado. Fundação de Estudos Agrários Luiz de Queiroz, Piracicaba, pp. 67-119.

VINSON S.B. 1998: The general host selection behavior of parasitoid Hymenoptera and a comparison of initial strategies utilized by larvaphagous and oophagous species. - Biol. Contr. 11: 79-96.

Voinovich N.D., Vaghina N.P. \& Reznik S.Y. 2013: Effects of cold shock on host egg parasitization by females of Trichogramma buesi Voegele (Hymenoptera, Trichogrammatidae). - Entomol. Rev. 93: 405-411.

Zibaee I., Mahmood K., Esmaeily M., Bandani A.R. \& KristensEN M. 2017: Organophosphate and pyrethroid resistances in the tomato leaf miner Tuta absoluta (Lepidoptera: Gelechiidae) from Iran. - J. Appl. Entomol. 142: 181-191.

Received June 5, 2019; revised and accepted January 3, 2020 Published online March 5, 2020 